\title{
Original
}

\section{Pretreatment with N-Acetylcysteine Protects against Cold Ischemia/Reperfusion Injury in the Rat Liver}

\author{
Hiroshi NaKano, Hideaki Nagasaki, Gaku Kigawa, Naoyasu Kitamura, \\ Kouzo Yoshida, Yoshiya Kaneshiro, Sei Takeuchi, \\ Masahiko Yamaguchi and Kaoru Kumada
}

\begin{abstract}
Ischemia-reperfusion injury resulting from production of reactive oxygen intermediates is one of the most likely pathophysiologic causes of liver dysfunction after liver transplantation. Glutathione is an essential endogenous antioxidant, and $\mathrm{N}$-acetylcysteine (NAC) is a nontoxic precusor of glutathione. The aim of the present study was to examine whether NAC administration protects against cold ischemia-reperfusion injury in the rat liver. An isolated perfused rat liver model subjected to prolonged hypothermic ischemia, 48-hour cold storage, and 120 minutes of reperfusion was employed. Administration of NAC 15 minutes before liver harvest significantly reduced concentrations of liver enzymes released into perfusate samples and significantly increased glutathione concentration in liver tissue specimens compared with those after administration of $5 \%$ dextrose. A glutathione-depleted liver was produced with intraperitoneal injection of buthionine sulfoximine, an inhibitor of $\gamma$-glutamylcysteine synthetase, 2 hours before intraportal administration of either NAC or $5 \%$ dextrose. Administration of NAC also reduced concentrations of liver enzymes released into perfusate samples compared with those after $5 \%$ dextrose injection. These results suggest that NAC administration reduces cold ischemiareperfusion injury in the rat liver by acting as a substrate for glutathione synthesis and also as a self-scavenger of reactive oxygen intermediates.
\end{abstract}

Key words: N-acetylcysteine, cold ischemia-reperfusion injury, glutathione, buthionine sulfoximine, reactive oxygen intermediates

\section{Introduction}

Ischemia-reperfusion injury is now a likely pathophysiologic cause of liver dysfunction after liver transplantation ${ }^{1)}$. Among numerous mechanisms of cold ischemia-reperfusion injury at liver transplantation, the production of reactive oxygen intermediates (ROIs) has been shown to be a main cause ${ }^{2)}$.

Reduced-form glutathione (GSH) is an essential endogenous antioxidant against ROIs. However, exogenous administration of GSH is ineffective owing to its limited absorption by hepatocytes and to a suppressive feedback system:). Cysteine is a key precursor and a rate-limiting factor in GSH synthesis. However, exogenously administered cysteine is quite toxic and ineffective ${ }^{4)}$.

N-Acetylcysteine (NAC) is a nontoxic precursor of GSH. Our previous study established Department of Surgery, Showa University Fujigaoka Hospital, 1-30 Fujigaoka, Aoba-ku, Yokohama 227, Japan. 
that NAC protects against warm ischemia-reperfusion injury. We showed that treatment of rats with NAC 15 minutes before induction of partial ischemia attenuates hepatic injury.

The aim of the present study was to investigate whether NAC administration 15 minutes before liver harvest protects against cold ischemia-reperfusion in the rat liver.

\section{Materials and Methods}

Male Wistar rats weighing 250 to $350 \mathrm{~g}$ (Japan Laboratory Animals Inc., Tokyo, Japan) were used. All animals were housed in a controlled environment $\left(22^{\circ} \mathrm{C}\right.$, constant air exchange). Rats were fasted overnight for 12 hours before experiments, but had free access to water. Surgical procedures were performed under ether anesthesia.

The abdomen was entered through a transverse subcostal incision. The superior mesenteric vein was then dissected distally to inject either $1 \mathrm{ml}$ dextrose $5 \%$ (D5\% group, $\mathrm{n}=10$ ) or $1 \mathrm{ml}$ dextrose $5 \%$ containing $150 \mathrm{mg} / \mathrm{kg}$ body weight of NAC (NAC group, $\mathrm{n}=10$ ). In two other groups, $2 \mathrm{mM} / \mathrm{kg}$ of buthionine sulfoximine (BSO), which is an inhibitor of $\gamma$-glutamylcysteine synthetase, was administered intraperitoneally 2 hours before the injection of either $1 \mathrm{ml}$ dextrose $5 \%$ (BSO-D5\% group, $\mathrm{n}=7$ ) or $1 \mathrm{ml}$ dextrose $5 \%$ containing 150 $\mathrm{mg} / \mathrm{kg}$ body weight of NAC (BSO-NAC group, $\mathrm{n}=9$ ). Fifteen minutes after injection of NAC or D5\%, a 16-gauge catheter was inserted into the portal vein. Then, livers were harvested with $100 \mathrm{ml}$ cold $\left(4^{\circ} \mathrm{C}\right)$ University of Wisconsin (UW) solution, and stored for 48 hours at $4^{\circ} \mathrm{C}$.

Livers were perfused with Krebs-Henseleit bicarbonate buffer (KHB) containing 5\% bovine serum albumin $\left(\mathrm{pH} 7.4 ; 37^{\circ} \mathrm{C}\right)$. The perfusate was pumped through the portal cannula with a peristaltic pump (Polystat; Ismatec Lab, Zürich, Switzerland) at a constant flow rate of $3.0 \mathrm{ml} / \mathrm{min} / \mathrm{g}$ of wet liver weight and gassed with carbogen $\left(95 \% \mathrm{O}_{2}, 5 \%\right.$ $\mathrm{CO}_{2}$ ). Livers were initially perfused for 5 minutes in a single-pass mode, and then perfused for 120 minutes in a recirculating mode with $200 \mathrm{ml}$ KHB. Five-milliliter samples of perfusate were collected from the perfusion chamber after 30, 60, and 120 minutes of perfusion (perfusion samples T30, T60, and T120, respectively). Perfusion samples were immediately frozen at $-80^{\circ} \mathrm{C}$ for later analysis of lactate dehydrogenase (LDH), aspartate aminotransferase (AST), acid phosphatase (ACP), GSH, and oxidized glutathione (GSSG). At the end of reperfusion, small cubes of liver tissue were removed from the left lateral lobe and frozen in liquid nitrogen followed by storage at $-80^{\circ} \mathrm{C}$ for later analysis of $\mathrm{GSH}$ and GSSG.

The concentrations of GSH and GSSG in the perfusate samples and in the tissue samples were separately measured with high-performance liquid chromatography (HPLC) as described by Reed et al..$^{5)}$ and as modified by us.

A ready-to-use commercial solution of NAC (Fluimucil ${ }^{\circledR}$, Laboratories Zambon, Antibes,

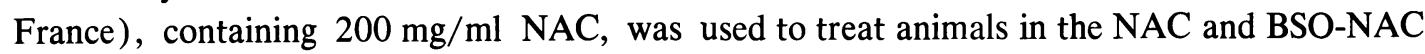
groups. BSO was purchased from Sigma Chemical Co. (L'isle d'Abeau, France).

Values are given as mean \pm standard error of mean (s.e.m.), and expressed per gram of wet liver weight. Statistical analyses were performed with the Mann-Whitney U-test using the computer software package Statview IV (Abacus Concepts Inc, Berkeley, CA, USA).

\section{Results}

Release of AST into perfusate samples was significantly lower in the NAC group than 
Table 1. The values of AST, LDH and ACP released into perfusate samples during reperfusion after 48 -hour cold storage, affected by $\mathrm{N}$-acetylcysteine (NAC) pretreatment or buthionine sulfoximine (BSO) and NAC pretreatment.

\begin{tabular}{|c|c|c|c|c|c|c|}
\hline \multirow{2}{*}{ Enzymes } & \multicolumn{2}{|c|}{ T30 } & \multicolumn{2}{|c|}{ T60 } & \multicolumn{2}{|c|}{$\mathrm{T} 120$} \\
\hline & $\mathrm{D} 5 \%(\mathrm{n}=10)$ & $\mathrm{NAC}(\mathrm{n}=10)$ & $\mathrm{D} 5 \%(\mathrm{n}=10)$ & NAC $(n=10)$ & D5\% $(n=10)$ & NAC $(n=10)$ \\
\hline $\begin{array}{l}\text { AST } \\
\text { (IU/l/g liver) }\end{array}$ & $5.30 \pm 1.30$ & $1.57 \pm 0.36^{*}$ & $12.03 \pm 2.75$ & $3.71 \pm 1.02^{*}$ & $38.75 \pm 5.62$ & $13.94 \pm 3.50^{\circ}$ \\
\hline $\begin{array}{l}\text { LDH } \\
\text { (IU/1/g liver) }\end{array}$ & $339.0 \pm 74.1$ & $90.8 \pm 30.5^{\circ}$ & $642.1 \pm 137.0$ & $206.6 \pm 59.1^{*}$ & $1891.3 \pm 268.3$ & $679.4 \pm 174.4^{\circ}$ \\
\hline $\begin{array}{l}\text { ACP } \\
\text { (IU/1/g liver) }\end{array}$ & $232.3 \pm 82.6$ & $20.9 \pm 12.3^{\circ}$ & $414.0 \pm 107.0$ & $71.9 \pm 22.1 *$ & $927.3 \pm 150.8$ & $344.4 \pm 89.6^{\circ}$ \\
\hline & $\begin{array}{c}\text { BSO-D5\% } \\
(\mathrm{n}=7)\end{array}$ & $\begin{array}{c}\text { BSO-NAC } \\
(n=9)\end{array}$ & $\begin{array}{c}\text { BSO-D5\% } \\
(\mathrm{n}=7)\end{array}$ & $\begin{array}{c}\text { BSO-NAC } \\
(n=9)\end{array}$ & $\begin{array}{c}\text { BSO-D5\% } \\
(n=7)\end{array}$ & $\begin{array}{c}\text { BSO-NAC } \\
(n=9)\end{array}$ \\
\hline $\begin{array}{l}\text { AST } \\
\text { (IU/1/g liver) }\end{array}$ & $16.55 \pm 3.15$ & $10.48 \pm 1.83^{*}$ & $37.56 \pm 6.25$ & $22.53 \pm 3.42^{*}$ & $112.45 \pm 14.19$ & $64.18 \pm 10.71 *$ \\
\hline $\begin{array}{l}\text { LDH } \\
\text { (IU/1/g liver) }\end{array}$ & $1093.2 \pm 236.8$ & $605.6 \pm 87.8^{*}$ & $2073.4 \pm 293.3$ & $1168.8 \pm 162.0^{*}$ & $4483.9 \pm 476.3$ & $3086.9 \pm 422.6^{*}$ \\
\hline $\begin{array}{l}\text { ACP } \\
\text { (IU/1/g liver) }\end{array}$ & $59 \pm 9$ & $33 \pm 3^{\circ}$ & $103 \pm 15$ & $54 \pm 5^{\circ}$ & $202 \pm 37$ & $108 \pm 14^{*}$ \\
\hline $\begin{array}{l}\text { Either } 1 \mathrm{ml} \\
\text { weight of } \mathrm{N} \\
2 \mathrm{mM} / \mathrm{kg} \text { of } \\
\text { tion of eithe } \\
\mathrm{mg} / \mathrm{kg} \text { body } \\
\text { lating reperfu } \\
\text { of reperfusio } \\
{ }^{\circ} \mathrm{p}<0.01, *\end{array}$ & $\begin{array}{l}\text { of } 5 \% \text { dextro } \\
\text {-acetylcysteine } \\
\text { buthionine su } \\
1 \mathrm{ml} \text { of } 5 \% \\
\text { weight of NA } \\
\text { ision chamber } \\
\text { n. Values are } \\
\text { p }<0.05 \text { (D5\% }\end{array}$ & $\begin{array}{l}\text { (D5\% group } \\
\text { NAC group) } \\
\text { ximine (BSO } \\
\text { xtrose } 5 \% \text { ( } \\
\text { (BSO-NAC } \\
60 \text {, and } 120 \\
\text { expressed as } \\
\text { vs. NAC, or } \mathrm{P}\end{array}$ & $\begin{array}{l}\text { or } 1 \mathrm{ml} \text { of } \\
\text { was injected } 1 \\
\text { ) was administ } \\
\text { BSO-D5 } \% \text { grou } \\
\text { group). Perfusi } \\
\text { minutes (T30, } \\
\text { mean } \pm \text { standard } \\
\text { BSO-D5\% vs. B }\end{array}$ & $\begin{array}{l}5 \% \text { dextrose } \\
5 \text { minutes bef } \\
\text { tered intraperi } \\
\text { p) or } 1 \mathrm{ml} \text { of } \\
\text { ion samples w } \\
\text { T60 and T } 120 \\
\text { d error of me } \\
3 S O-N A C ; M a\end{array}$ & $\begin{array}{l}\text { ontaining } 150 \mathrm{r} \\
\text { liver harvest. } \\
\text { leally } 2 \text { hours } \\
\text { \% dextrose cor } \\
\text { collected from } \\
\text { espectively) aft }\end{array}$ & $\begin{array}{l}\mathrm{mg} / \mathrm{kg} \text { body } \\
\text { In addition, } \\
\text { before injec- } \\
\text { ntaining } 150 \\
\text { the recircu- } \\
\text { ter induction }\end{array}$ \\
\hline
\end{tabular}

in the D5\% group (Table 1). Similarly, release of LDH into the perfusate samples was significantly lower in the NAC group than in the D5\% group. The concentration of ACP in the perfusate samples was lower in the NAC group than in the D5\% group. The concentrations of GSH and GSSG in the liver tissue samples were significantly higher in the NAC group than in the D5\% group (Table 2). The concentration of GSH in the perfusate samples was higher in the NAC group than in the D5\% group. The concentration of GSSG in the perfusate samples was significantly lower in the NAC group than in the D5\% group.

When rat livers were pretreated intraperitoneally with BSO, AST and LDH concentrations were significantly lower in the BSO-NAC group than in the BSO-D5\% group (Table 1). Moreover, the ACP concentration was significantly lower in the BSO-NAC group.

\section{Discussion}

Gores and his colleagues showed that hepatocellular blebs, which are formed on the surface of hepatocellular membranes and protrude into the sinusoidal lumen during cold preservation, are torn off and released into sinusoidal blood flow after reperfusion (i.e., bleb 
Table 2. Concentrations of reduced-form glutathione (GSH) and oxidized-form glutathione (GSSG) in perfusate or liver tissue samples.

\begin{tabular}{cccccc}
\hline \multirow{2}{*}{ Group } & \multicolumn{2}{c}{ Perfusate samples (T120) } & & \multicolumn{2}{c}{ Liver tissue samples (T120) } \\
\cline { 2 - 3 } \cline { 5 - 6 } & $\begin{array}{c}\text { GSH } \\
(\mathrm{nmol} / \mathrm{l} / \mathrm{g} \text { liver })\end{array}$ & $\begin{array}{c}\text { GSSH } \\
(\mathrm{nmol} / \mathrm{l} / \mathrm{g} \text { liver })\end{array}$ & & $\begin{array}{c}\text { GSH } \\
(\mu \mathrm{mol} / \mathrm{g} \text { liver })\end{array}$ & $\begin{array}{c}\text { GSSG } \\
(\mu \mathrm{mol} / \mathrm{g} \text { liver })\end{array}$ \\
\hline NAC $(\mathrm{n}=10)$ & $777 \pm 98$ & $525 \pm 126^{*}$ & & $7.30 \pm 0.97^{*}$ & $0.74 \pm 0.06^{*}$ \\
D5\% $(\mathrm{n}=10)$ & $666 \pm 134$ & $927 \pm 137$ & & $4.13 \pm 1.00$ & $0.46 \pm 0.07$ \\
\hline
\end{tabular}

Either $1 \mathrm{ml}$ of $5 \%$ dextrose (D5\% group) or $1 \mathrm{ml} \mathrm{of} 5 \%$ dextrose containing $150 \mathrm{mg} / \mathrm{kg} \mathrm{body}$ weight of $\mathrm{N}$-acetylcysteine (NAC group) was injected 15 minutes before liver harvest. The values of GSH and GSSG at the end of reperfusion (T120) are presented. Liver tissue samples were obtained at the end of reperfusion. These values were measured with HPLC. Values are expressed as mean \pm standard error of mean.

* $\mathrm{p}<0.05$ (D5\% vs. NAC; Mann-Whitney U test).

shedding). They aggravate reperfusion injury through microcirculatory obstruction by acting as emboli(i). Moreover, ROIs enhance hepatocellular bleb formation and bleb shedding after reperfusion, resulting in an increased release of hepatocellular cytosolic enzymes, such as AST or $\mathrm{LDH}$, into the sinusoidal lumen ${ }^{i, 8}$. These findings suggest that the significantly lower concentrations of AST and LDH in the perfusate samples in the NAC group than in the D5\% group indicate that NAC protects hepatocytes against ROIs produced during reperfusion after cold preservation. This protective effect in hepatocytes might be explained by the significantly higher concentration of GSH in the liver tissue samples from the NAC group, suggesting that NAC protects against injury by ROIs by acting as a substrate for GSH synthesis.

Caldwel-Kenkel and his colleagues have shown in their cold preservation-reperfusion model that ACP concentrations in perfusate samples correlate with Kupffer cell activation ${ }^{2}$. Furthermore, Kupffer cells release ACP and ROIs into the sinusoidal lumen just after the start of reperfusion ${ }^{2,9)}$. Jaeschke and Farhood have shown that sinusoidal oxidant stress caused by Kupffer cell activation plays an important role in ischemia-reperfusion injury ${ }^{10)}$. In the present study, the significantly lower ACP concentration in the NAC group might indicate less oxidant stress in the sinusoidal lumen during reperfusion. The decreased oxidant stress in the sinusoidal lumen of the NAC group seemed to be indirectly confirmed by the significantly lower concentration of GSSG in the perfusate samples from the NAC group.

BSO is an inhibitor of $\gamma$-glutamylcysteine synthetase which can decrease plasma GSH as well as hepatic $\mathrm{GSH}^{11)}$. This effect of $\mathrm{BSO}$ is explained by the fact that BSO inhibits GSH efflux from hepatocytes into the sinusoidal lumen and GSH synthesis in hepatocytes, because the concentration of plasma GSH in the rat is determined mainly by GSH release from hepatocytes $^{12)}$. The significantly lower concentrations of AST, LDH, and ACP in the BSONAC group than in the BSO-D5\% group might indicate that NAC protects against hepatocellular injury and inhibits Kupffer cell activation by acting as a self-scavenger of ROIs.

In conclusion, NAC seems to protect against cold ischemia-reperfusion injury in the rat liver by acting as a self-scavenger of ROIs and as a precursor of GSH during reperfusion. 


\section{References}

1) Clavien PA, Harvey PR and Strasberg SM: Preservation and reperfusion injuries in liver allografts. An overview and synthesis of current study. Transplantation, 53: 957-978 (1992)

2) Caldwell-Kenkel JC, Currin RT, Tanaka Y, Thurman RG and Lemasters JJ: Kupffer cell activation and endothelial cell damage after storage of rat livers: effect of reperfusion. Hepatology, 13: 83-95 (1991)

3) Kobayashi H, Kurokawa $\mathrm{T}$ and Kitahara S: The effects of $\gamma$-glutamylcysteine ethyl ester, a prodrug of glutathione, on ischemia-reperfusion-induced liver injury in rats. Transplantation, 54: 414-418 (1992)

4) Simmons TW, Anders MW and Ballatori N: L-Cysteine and S-(1,2-dichlorovinyl)-L-cysteine transport in rat liver canalicular membrane vesicle: potential reabsorption mechanisms for biliary metabolites of glutathione and its S-conjugates. J Pharmacol Exp Ther, 262: 1182-1188 (1992)

5) Reed DJ, Babson JR, Beatty PW, Brodie ARE, Ellis WW and Potter DW: High-performance liquid chromatography analysis of nanomole levels of giutathione, glutathione disulfide, and related thiols and disulfides. Anal Biochem Pharmacol, 106: 55-62 (1980)

6) Gores GJ, Herman B and Lemasters JJ: Plasma membrane bleb formation and rupture: a common feature of hepatocellular injury. Hepatology, 11: 690-698 (1990)

7) Jaeschke H: Enhanced sinusoidal glutathione efflux during endotoxin-induced oxidant stress in vivo. Am J Physiol, 263: G60-G68 (1992)

8) Fratté S, Gendrault JL, Steffan AM and Kirn A: Comparative ultrastructural study of rat liver preserved in Euro-Collins or University of Wisconsin solution. Hepatology, 13: 1173-1180 (1991)

9) Jones EA and Summerfield JA: Kuffer cells. In: The Liver: Biology and Pathology. Arias IM, Jakoby WB, Popper H, Schacter D and Shafritz DA (Eds), Raven Press, New York, pp 683-704 (1988)

10) Jaeschke $\mathrm{H}$ and Farhood A: Neutrophil and Kupffer cell-induced oxidant stress and ischemia-reperfusion injury in rat liver. Am J Physiol, 260: G355-G362 (1991)

11) Aebi S and Lauterburg BH: Divergent effects of intravenous GSH and cysteine on renal and hepatic GSH. Am J Physiol, 263: R348-R352 (1992)

12) Lauterburg BH, Adams JD and Mitchell JR: Hepatic glutathione homeostasis in the rat: efflux accounts for glutathione turnover. Hepatology, 4: 586-590 (1984)

[Received July 29, 1997: Accepted September 3, 1997] 